\title{
ANALYZING RELIGION AND TRUST RELATIONSHIP FROM TURKISH PERSPECTIVE*
}

Murat YILMAZ

\section{Article Information}

Article Types: Research Article, Received: 5 June 2021, Accepted: 30 September 2021, Published: 30 September 2021, Cite as: Yllmaz, Murat." Analyzing Religion And Trust Relationship From Turkish Perspective". Journal of Academic Research in Religious Sciences 21/2 (September 2021): 909-937.

https://doi.org/10.33415/daad.948160

\section{Makale Bilgisi}

Makale Türü: Araştırma Makalesi, Geliş Tarihi: 5 Haziran 2021, Kabul Tarihi: 30 Eylül 2021, Yayın Tarihi: 30 Eylül 2021, Atıf: Yılmaz, Murat. "Din ve Güven İlişkisinin Türkiye Perspektifinden İncelenmesi”. Dinbilimleri Akademik Araştırma Dergisi 21/2 (Eylül 2021): 909-937.

https://doi.org/10.33415/daad.948160

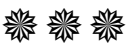

\section{Abstract}

This article investigates the relationship between religion and trust using the Turkish sample from the World Values Surveys (WVS). This study focuses on a majority Muslim nation that has been institutionally secular and democratic for more than 90 years. This study explores the longitudinal relationship between religion and trust from 2001 to 2012, a period of significant social transformation.

Over this period, the effects of religion's covariates on trust outcomes are consistent. However, the findings explore mix supports to the existing literature. Namely, the effects of religious affiliation and behaviour vary on trust outcomes. This study also investigates possible correlations between trust components, and the results do not support the previous findings.

Keywords: Religion, Trust, Islam, Turkey, Sociology.

This article is extracted from my masters dissertation entitled "Religion and Trust: Turkish Case", (M.D. Dissertation, Sociology Department 2015)

* Assistant Professor Dr., Hitit University, Faculty of Theology, Department of Sociology of Religion muratyilmaz@hitit.edu.tr; Orcid Id: https://orcid.org/0000-0001-70834981 


\section{Din ve Güven İlişkisinin Türkiye Perspektifinden İncelenmesi}

Öz

Bu çalışma Dünya Değerler Araștırmaları'ndan (WVS) alınan Türkiye örneğini kullanarak din ve güven arasındaki ilişkiyi araştırmaktadır. Bu konuda çoğunlugu Batı'da yapılmış olan araştırmaların aksine 90 yıldan uzun süredir kurumsal olarak laik ve demokratik olmasına karşın çoğunluğunu Müslümanların oluşturduğu bir ülkeye odaklanmaktadır. Türkiye açısından önemli bir sosyal dönüşüm dönemi olan 2001'den 2012'ye kadar din ve güven arasındaki uzun vadeli ilişkinin araştırıldığı bu makalede, dinin ortak değişkenlerinin güven sonuçları üzerindeki etkilerinin tutarlı olduğu gözlemlenmiştir. Bununla birlikte, her ne kadar bulgular mevcut literatürü desteklemiş olsa da bazı farklılıklar arz etmektedir. Bir başka deyişle, dini bağlılığı ve davranışları içeren değişkenlerin etkileri, güven değişkenlerine bağlı olarak farklılaşmaktadır. Ayrıca güven değişkenleri arasındaki olası korelasyonlar ortaya koyulmuş ve elde edilen bulgular Batı'da yapılmış olan çalışmalardaki teorik ve ampirik izahat ve sonuçları desteklememektedir.

Anahtar Kelimeler: Din, Güven, İslam, Türkiye, Sosyoloji

\section{Introduction}

Marx, Durkheim and Weber all paid close attention to the question of "what holds society together?" While proposing distinct theoretical systems, they all agreed that social cohesion is based on common beliefs shared by members of traditional societies, and becomes based on "social and economic interdependence" in modern societies ${ }^{1}$. Hunter argues that modern societies, like traditional societies, need a modicum of shared beliefs and ideas to avoid societal breakdown.

This study utilizes the concept of "trust" as a measure of social cohesion to analyze the relationship between religion and social cohesion. The current literature on trust focuses predominantly on Western Judeo-Christian societies. Consequently, we know very little about how trust functions in the other parts of the world. This study fills this gap and offers a comparative perspective for possible differences or similarities between Western societies and a Muslimmajority country. Compared to other Muslim countries, Turkey is unique not only its geographical position and socio-cultural heritage but also data availability and the variance level within religious measures.

James Davison Hunter, To Change the World: The Irony, Tragedy, and Possibility of Christianity in the Late Modern World (New York: Oxford University Press, 2010), 101. 
This study gauges that trust concept has distinct nature in Turkish society in several ways. First, religion is a significant determinant for trust outcomes and mostly consistent overtime periods, but the directions of relationship are various among trust outcomes. Further, the findings illustrate that the present study contradicts with the existing hypothesis that trust in strangers is positively correlated with political trust (confidence in government, parliament and political parties).

\section{Trust and Religion}

Trust (specifically generalized trust) is recognized as an important component of social cohesion ${ }^{2}$. Yet some assert that modern societies might have less overall need for trust due to centralized institutional power ${ }^{3}$. On the other hand, the rise of pluralism and individualism might increase the need for trust as a moral value which helps to integrate diverse populations.

A common definition of trust is "the expectation that arises within a community of regular, honest and cooperative behaviour, based on commonly shared norms, on the part of other members of the community"4. Putnam $(1994)^{5}$ suggested that trust is the foundation of social life and a key facilitator of social capital. Similarly, Uslaner (2004) ${ }^{6}$ depicts trust as a moral value which fosters social bonds between people. As such, high levels of trust facilitate collective action, civic engagement, and cooperative economic models for nations ${ }^{7}$. On the other hand, low levels of trust undermine civil engagement, enhance social isolation, and undermine market efficiency ${ }^{8}$.

2 Jan Delhey - Kenneth Newton, "Who trusts?: The origins of social trust in seven societies", European Societies 5/2 (01 Ocak 2003), 93-137.

3 Barbara Misztal, Trust in Modern Societies: The Search for the Bases of Social Order (Polity, 2013).

4 Francis Fukuyama, Trust: The Social Virtues and The Creation of Prosperity (New York, NY: Free Press, 1996), 26.

5 Robert D. Putnam, "Social Capital and Public Affairs", Bulletin of the American Academy of Arts and Sciences 47/8 (1994), 5-19.

6 Eric M. Uslaner, "Trust and Social Bonds: Faith in Others and Policy Outcomes Reconsidered", Political Research Quarterly 57/3 (2004), 501-507.

7 Robert D. Putnam vd., Making Democracy Work: Civic Traditions in Modern Italy (Princeton, NJ: Princeton University Press, 1994).

8 Eric M. Uslaner - Mitchell Brown, "Inequality, Trust, and Civic Engagement", American Politics Research 33/6 (01 Kasım 2005), 868-894. 
According to previous studies, trust has three distinctive components: generalized or social trust (trust in strangers), particular trust (trust in known people), and institutional trust (confidence in government, parliament, schools, etc.) ${ }^{9}$. These three components of trust are positively correlated in most democratic countries; generalized trust is most strongly correlated with institutionalized trust ${ }^{10}$. These relationships also exist in Arab countries, Egypt, Jordon and Morocco, even though overall levels of trust are much lower ${ }^{11}$. Jamal argues low levels of trust in these countries actually might be a good sign for the development of democracy because it is related to the growing number of critical citizens who are not happy with the current social and political status quo.

There are several explanations for why levels of social trust vary dramatically across nations ${ }^{12}$. Putnam $(2000)^{13}$ argues that when people become members of civic associations, they naturally develop interpersonal communication which fosters a more trusting environment. Inglehart (1999) ${ }^{14}$ found that religious traditions play a significant role for the dissimilarities among nations. For example, Protestant and Confucian cultures produce more trust than Catholic or Muslim societies. La Porta et al (1997) ${ }^{15}$ proposed that because Catholicism and Islam are hierarchical religions, they are associated with lower level of generalized trust. In addition, Alesina and La Ferrara (2002) $)^{16}$ argue that religious similarities enhance a more trusting environment while dissimilarities undermine social cohesion. Quite simply, homogenous communities are more trusting, suggesting that religious pluralism undermines trust in general. Durkheim defined religion as "a unified system of be-

9 Adam John Sullivan, Social Trust and Denominational Concentration: A Cross-National Examination of Religion and Trust (ProQuest Dissertations Publishing, 2013).

10 Sonja Zmerli - Marc Hooghe, Political Trust: Why Context Matters (ECPR Press, 2013).

11 Amaney Jamal, "When Is Social Trust a Desirable Outcome? Examining Levels of Trust in the Arab World", Comparative Political Studies 40/11 (11 Ocak 2007), 13281349.

12 Jong-sung You, "Social Trust: Fairness Matters More Than Homogeneity", Political Psychology 33/5 (01 Ekim 2012), 701-721.

13 Robert Putnam, Bowling Alone: The Collapse and Revival of American Community (New York: Simon \&amp; Schuster, 2000).

14 Ronald Inglehart, "Trust, well-being and democracy", Democracy and Trust, ed. Mark E. Warren (Cambridge: Cambridge University Press, 1999), 88-120.

${ }^{15}$ Rafael La Porta vd., "Trust in Large Organizations", The American Economic Review 87/2 (1997), 333-338.

16 Alberto Alesina - Eliana La Ferrara, "Who Trusts Others?", Journal of Public Economics 85/2 (01 Ağustos 2002), 207-234. 
liefs and practices relative to sacred things, that is to say, things set apart and forbidden - beliefs and practices which unite into one single moral community called a Church, all those who adhere to them" (1954, p.47) $)^{17}$. Religion generates a community bond that keeps community members together and promotes social networks $^{18}$. For Durkheim, social solidarity is premised on common beliefs and values, and in order to prevent anomie, all societies need a common "morality." While he believed traditional religion is weaker in modern settings, Durkheim maintained that shared morality was key to establishing social integration and social order (organic solidarity) in complex societies ${ }^{19}$. Gellner $(2000)^{20}$ states religion provides a common language for different groups within society; as such, religions can provide the conceptual foundation of trust in complex societies.

Alesina and Ferrara $(2002)^{21}$ suggest that trust is also central to religious activity. In short, religious ritual and belief promote and sustain trust among religious adherents ${ }^{22}$. This link is explained by demonstrating how religion gives adherents shared values and common purposes ${ }^{23}$. A vast amount of research finds a positive connection between worship attendance, religious beliefs, and the generalized trust ${ }^{24} ; 25,26,27,28,29 ; 30$. However, the relationship

17 Émile Durkheim - Joseph Ward Swain, The Elementary Forms of the Religious Life. (Glencoe, Ill.: Free Press, 1954), 47.

18 Rosemary Leonard - John Bellamy, "The Relationship between Bonding and Bridging Social Capital among Christian Denominations across Australia", Nonprofit Management and Leadership 20/4 (2010), 445-460.

19 Misztal, Trust in Modern Societies, 61.

20 Ernest Gellner, Trust, Cohesion, and the Social Order, 2000, 142-157.

21 Alesina - La Ferrara, "Who Trusts Others?"

22 RONALD INGLEHART, Modernization and Postmodernization: Cultural, Economic, and Political Change in 43 Societies (Princeton University Press, 1997).

23 Sullivan, Social Trust and Denominational Concentration.

24 Corwin Smidt, "Religion and Civic Engagement: A Comparative Analysis", The ANNALS of the American Academy of Political and Social Science 565/1 (01 Eylül 1999), 176-192.

25 Michael R. Welch vd., "Trust in God and Trust in Man: The Ambivalent Role of Religion in Shaping Dimensions of Social Trust", Journal for the Scientific Study of Religion 43/3 (2004), 317-343.

26 James Proctor, "Religion as Trust in Authority: Theocracy and Ecology in the United States", Annals of the Association of American Geographers 96/1 (01 Mart 2006), 188196.

27 Jonathan H. W. Tan - Claudia Vogel, "Religion and Trust: An Experimental Study", Journal of Economic Psychology 29/6 (01 Aralık 2008), 832-848. 
between religion and trust is somewhat complex and mixed ${ }^{31}$. Welch et al. (2004) ${ }^{32}$ noted that the relationship between religious attendance and social trust is not significant when controlling for religious tradition ${ }^{33}$. Also, Alesina and La Ferrara (2002) ${ }^{34}$ report insignificant effect of religious affiliation in Protestant, Catholic, Jewish, and other religions.

The concept of trust from an Islamic perspective is unclear although there are many Quranic teachings about trust. The Quran $(2: 186 ; 3: 122 ; 40: 8 ; 5: 1)$ clearly states that Muslims should place their trust only in Allah and be trustworthy. This requires Muslims to be trustworthy themselves but not necessarily trusting of strangers, because humans are understood to be unreliable by their nature.

\section{Turkey's Socio-Political Background}

After the establishment of a new Turkish state (1923), Ataturk 914 $\mathrm{db}$ famously sought to force religion out of the political and public spheres. He saw religion as a barrier to modernization and regulated religious activities and institutions heavily in an attempt to secularize Turkish culture. In addition, Ataturk created an ideology, called Kemalism, which was intended to replace all religion with elements of nationalism and laicism (secularism). To this end, he took control of all major social institutions, making them subordinates to state power. Religious schools became state schools and their educators and curriculum were chosen by the government. In this process, ideological, religious, and ethnic diversity within Turkey was spurned and suppressed in order to create a unified modern, secular, and nationalist society. Ataturk's cultural reorganization is now seen as having fueled many of today's conflicts in Tur-

28 F. Carson Mencken vd., "In God We Trust: Images of God and Trust in the United States among the Highly Religious", Sociological Perspectives 52/1 (01 Mart 2009), 23-38.

29 Richard Traunmüller, "Moral Communities? Religion as a Source of Social Trust in a Multilevel Analysis of 97 German Regions", European Sociological Review 27/3 (01 Haziran 2011), 346-363.

30 Joseph P. Daniels - Marc von der Ruhr, "Trust in Others: Does Religion Matter?", Review of Social Economy 68/2 (01 Haziran 2010), 163-186.

31 Daniels - Ruhr, "Trust in Others".

32 Welch vd., "Trust in God and Trust in Man".

33 Sullivan, Social Trust and Denominational Concentration.

${ }^{34}$ Alesina - La Ferrara, "Who Trusts Others?" 
key, especially those between religious, secular, Turk, Kurd, and Alawi people.

The new Turkish state established educational unity and promoted Western culture and thinking, to establish the value of secularism in Turkey. Previous studies show that public education had a negative effect on religious belief and practice and a positive relationship with secularization (laicism). Current cultural and political divisions in Turkey --religious vs. laik--, are premised on this educational history.

Before the 1980s, the majority of the population was living in rural areas and was overwhelmingly religious. These rural Muslims adapted several new forms for resistance to the ruling system. The Imam-preacher high schools, which belong to the state's educational system, became one of the most important options for religious people, who immigrated to larger cities.

These Imam-preacher high schools also produced civilian organizations such as Nation Youth Foundation, (MGV). Students in these schools learn Islamic traditional knowledge such as Quran $\mathrm{db} \mid 915$ and the biography of the Prophet Muhammad. Furthermore, civilian organizations such as MGV foster collective resistance to the Kemalist system. In the 1990s, religious schools became increasingly popular and competitive in the nation-wide examination. Today, most of the governing elites such as president and prime minister are graduates from these schools. And after 2011 the government made a policy that makes the national examination condition equal among different type of high schools.

After the 1980s, political Islam experienced a rise within the Welfare Party (RP) which defined itself as an Islamic party. In fact, the party was a part of a religious movement called "Milli Gorus" (National Vision). The movement compasses foundations, civic organizations, mass media, and companies that bolster the ideals of the movement across the nation. The political rise of Islamists has been opposed by the secular part of the society and the military, which fears in the establishment of a religious state (something akin to Iran). The RP came to power in 1997 but was ended by a post-modern coup just 11 months later. Subsequently, the RP was closed as well as previous two Milli Gorus' parties. The soldiers whose wives were wearing headscarves and who prayed in the military bases were dismissed from the military. Some generals in the 
military said that this coup's effect would remain 1,000 years (www.worldbulletin.net/). In addition, imam-preacher high schools were shut down and people who graduated from these schools could only pursue degree at Divinity schools.

Just five years later, the Justice and Development Party (AKP), a pro-Milli Gorus faction, came to power. One of the significant reasons for the success of the AKP is the economic crisis of 2001 which was blamed on the administration of coalition parties. Many people lost their businesses and jobs. As a new party under charismatic leadership of Recep T. Erdogan, the AKP became the only hope for many people.

Opponents of the AKP accused it of carrying out a hidden Islamic agenda because of its Milli Gorus roots. Although the former Prime Minister current the President, Recep Tayyip Erdogan, has stated that AKP is not an Islamic Party and re-identified it as a "conservative and democrat party", this explanation has always been met with skepticism, and it is emphasized that in reality, the party has a hidden agenda to bring Turkey into a religious state by secularists. In fact, AKP failed to pass many bills in the first period of legislation because of vetoes from President Ahmet Nejdet Sezer, who identified himself as a true Kemalist.

The strengthening of political Islam has brought forth the question: is Turkey becoming a religious country? Particularly influencing this question is the fact that it took almost two-thirds of the seats in the 2002 election after fifteen months of its establishment. In Turkey today, religion is the main component of political conflict. For instance, the JDP (Justice and Development Party) and the RPP (Republic Public Party) have very similar economic goals but advocate different policies based on religious differences ${ }^{35}$.

Still, Turkey is overwhelmingly Muslim (99.8\%) yet officially democratic and secular, and one of the fastest developing country. Huntington (1996: 149) ${ }^{36}$ defines Turkey as "torn country" that has religious, secular, Eastern and Western characteristics. Within this religiously contentious political environment, how does Islam affect generalized, social, and institutional trust?

35 M. Emin Köksal, Din ve Siyaset - Siyasal Davranış ve Dindarlık (Ankara: Vadi, 1997).

36 Samuel P. Huntington, The Clash of Civilizations and the Remaking of World Order (Simon \& Schuster, 1998). 


\section{Turkish Society and Trust}

Several studies indicate that Turkey is among the lowest trusting countries in the world, comparable to Brazil, Peru, and Philippines $^{37} ; 38.39$. Li and Fung $(2013)^{40}$ compared 38 countries to analyze age differences in trust. Their findings show that Turkey has the lowest (.05) mean score for generalized trust among these countries while also having the highest mean (2.95) score for trust family members. Moreover, Sasaki and Marsh (2012) ${ }^{41}$ investigated trust in seven countries, Japan, U.S., Germany, Taiwan, Russia, the Czech Republic and Turkey, again finding the lowest trust level (\%10.2) in Turkey. The findings of this study illustrate that $86 \%$ and $88 \%$ of Turkish people think people in general are selfish and would try to take advantage of strangers, respectively. Also, $62 \%$ of Turkish people report that their parents teach that you "can't be too careful dealing with people".

However, the way this question was asked plays a significant role in explaining this variance. The question contrasts trust with "caution" not "distrust" The WVS 2001 is an exception because the wording for generalized trust is somewhat different than previous and later waves. The survey asked the same question but the second choice was "you need to be careful" in place of "you can't be too careful". Therefore, even though only five percent of Turkish citizens trust others this does not mean that 95\% of people distrust each other. Also, Turkish culture places high value on being a "cautious" person and not blindly trusting others. A common proverb in Turkey says "Essegi saglam kaziga bagla sonra Allah'a guven" ("put your trust in God, but keep your gun powder dry"). Thus, Turkish people might report high level of caution, but this may not be a sign of societal breakdown or outright hostility.

37 Delhey - Newton, "Who trusts?"

38 Faruk Ekmekçi, "Marazi bir durum olarak Türkiye'de niyet siyaseti: Türkiye'de toplumsal güven eksikliği ve bunun siyasal sonuçları", Uluslararası İnsan Bilimleri Dergisi 7/2 (2010).

39 Masamichi Sasaki - Robert M. Marsh, Trust: Comparative Perspectives (BRILL, 2012).

40 Tianyuan Li - Helene H. Fung, "Age Differences in Trust: An Investigation across 38 Countries", The Journals of Gerontology. Series B, Psychological Sciences and Social Sciences 68/3 (May1s 2013), 347-355.

41 Sasaki - Marsh, Trust. 
Based on the previous discussion the following hypotheses were expected:

H1: Generalized trust will be positively correlated with institutional trust.

H2: Religious affiliation and behaviour decrease the likelihood that a person will trust others (generalized trust).

H3: Religious affiliation and behaviour decrease the likelihood that a person will trust government and political parties in 2001.

H4: Religious affiliation and behaviour increase the likelihood that a person will trust government agencies (institutional trust) in 2007 and 2012.

H5: Religious affiliation and behaviour increase the likelihood that a person will trust friends, neighbours and family (particular trust).

H6: Religious affiliation and behaviour decrease the likelihood that a person will trust people who they meet first time, from other nations and other religions.

\section{Data and Methods}

In order to test the given hypotheses, longitudinal secondary data analyses were utilized in this paper. The data analyses were derived from the Turkey's World Values Surveys 2001, 2007 and 2012. The WVS is replicated cross-national which is conducted as face-to-face interview based on random probability sampling. The most important reason to use this data set instead of others such as the International Social Survey Program (ISSP) or the European Values Survey (EVS) is the possibility of investigating the existing relationship in different time points. The WVS also enables me to test various religious outcomes and trust components.

\section{Dependent Variables}

Generalized trust: Many previous studies on trust have used one standard item "most people can be trusted or that you can't be too 
careful in dealing with people"424344. The WVS asked this question in the same way in 2007 and 2012 "Generally speaking, would you say that most people can be trusted or that you can't be too careful in dealing with people", but it is asked differently in 2001 as "Generally speaking, would you say that most people can be trusted or that you need to be very careful in dealing with people"? The answer categories are recoded as: $0=$ most people can be trusted; $1=$ cannot be too careful in dealing with people. Only the last wave of the WVS includes several other generalized trust items that are used to make further assessments on generalized trust in Turkey. These items are trust in people who meet for the first time, who from different nationalities and different religions. The survey asked respondents: "I'd like to ask you how much you trust people you meet for the first time, people of another religion and People of another nationality: "Could you tell me for each whether you trust people from this group completely, somewhat, not very much or not at all?" The responses were recoded as $0=$ "not very much and not at all" and $1=$ "completely and somewhat".

Particular trust: The respondents were asked the previous question with same categories to answer how much they trust their families and neighbours, and people they know personally. The categories are recoded in the same manner.

Institutional trust: These variables consist of five different items. Although confidence has different meanings in the Turkish questionnaire, it asked as the same word with "trust in others". Therefore, confidence here has the exact same meaning with "trust". The respondents were asked respectively "how much confidence do you have in parliament, religious organizations, political parties, courts, government and army?" The responses are recoded as $0=$ "not confident" and $1=$ "confident"

\section{Independent Variables}

Religious: Subjective religiosity is the first religious predictor that illustrates self-report of personal religiosity. Respondents were asked "Independently of whether you attend religious services or not, would you say you are: a religious person, not a religious per-

42 John Brehm - Wendy Rahn, "Individual-Level Evidence for the Causes and Consequences of Social Capital", American Journal of Political Science 41/3 (1997), 999-1023.

43 Putnam, "Social Capital and Public Affairs".

44 Uslaner, "Trust and Social Bonds". 
son, an atheist. The response categories recoded as a dummy variable due to very little variance on atheist (less than 1 percent). The categories are $0=$ "not religious person or atheist" and $1=$ "a religious person".

Importance of God: The second independent variable intends to measure the level of importance respondents ascribe to god. This measure asked of respondents: "How important is God in your life? Please use this scale to indicate: 10 mean 'very important' and 1 means 'not at all important'." This variable is dichotomized so that involves only two categories. Here, $0=$ "less than very important," and 1 = "very important."

Importance of Religion: This variable is utilized as religious salience predictor that questions respondents: "Indicate how important religion is in your life. Would you say it is very important, rather important, not very important, or not at all important?" This variable is dummied so that $0=$ "less than very important", and 1 = "very important".

Attendance: The last religious measure captured how often respondents reported attending worship services. This outcome is here used to help predict individuals' institutional religious activity. As previous studies indicated that this measure is inherently gender-biased when utilized in the context of Turkish Muslim respondents, as Islamic tradition does not require women to attend mosque services as often as it requires men (Acevedo et al., 2013); only men are included in analyzing the attendance impact. The respondents asked "Apart from funerals, how often do you attend religious services?" The responses were recoded as $4=$ "daily"; $3=$ "weekly"; 2 = "in special days"; $1=$ "less often"; and $0=$ "never.

\section{Control Variables}

The six control variables employed in this analysis include respondents' age, gender, education (degree), employment, income, and marital status. The age and education variables are categorical; age has four categories $(1=15-29 ; 2=30-44 ; 3=45-64 ; 4=)$; and education has five categories $(0=$ "no education"; $1=$ "primary education"; 2 = "incomplete secondary"; $3=$ "some university"; 4= "university degree and higher"), while income is a ten step continuous variable. Gender, employment and marital status are dummy variables $1=$ "male", "employed" and "married" respectively. 


\section{Results}

Table 1, 2 and 3 feature the descriptive statistics for all of the variables included in this study within three waves respectively. The descriptive statistics in three waves demonstrate that the means for dependent variables are different from each other within each year and over time. The generalized trust is undoubtedly low and fluctuates over time from 18 percent in 2001, to 5 percent in 2007 and 13 percent in 2012. Also, the highest reported confidence level in all waves is confidence in armed forces by more than 80 percent in each wave with a slight decrease over time. Furthermore, there are considerable increases in confidence in government by over 16 percent and confidence in parliament by over 14 percent. Third, confidence in parties is relatively low compared to other institutional trust items, but increases marginally from 2001 to 2012. Confidence in religious organization and courts has increase slightly in 2012.

Table 3 includes several other general and particularized trust components. The mean scores of particularized trust items trust in family, neighbours and known people are extremely high, over 80 percent. Specifically, there is almost no variance in trust of family members, 99.3 percent. The remaining generalized trust variables show higher levels of trust than actual generalized trust items. The respondents trust people from different nations and religions by 40 and 38 percentages respectively while 23 percent they trust people who meet first time. Most clearly, H1 is not supported because the rise of confidence in institutions are not consistently linked to generalized trust measures. H1 is not supported.

Religiosity rises from 80 percent to 84 percent gradually, while importance of god and importance of religion decrease steadily from 80 percent to 66 percent. After one percent increase in 2007, a minor decline is observable in mosque attendance of male sample in 2012. The mean score illustrates that almost $2 / 3$ of the Turkish population attend mosque at least once a week.

According to the descriptive statistics, the average Turkish individual is female, married, adult, relatively poor, and has some high school education. From longitudinal perspectives, the mean scores for socioeconomic status indicators, income and education, 
increase considerable from 2001 to 2012 . These results are evidence of Turkey's development within last 12 years.

Table 4 includes six binary logistic regression models that derived from the WVS 2001and illustrates the odds ratios for generalized and institutional trust items. The models for institutional trust components show that religion is significant and the strongest determinant across models except confidence in political parties. Subjective religiosity is a significant and positive predictor for confidence in parliament, confidence in religious organization and confidence in government while importance of God is a significant and positive determinant for only confidence in religious organizations. The most powerful predictor for institutional trust is religious salience. Across models, except for trust of political parties, people who report religion is very important to them are over 50 percent more likely to express confidence in social institutions.

The logistic regression results in Table 4 show that religious predictors have a mixed effect on generalized trust. While subjective religiosity increases the likelihood of people trusting strangers by 60 percent, religious salience decreases the likelihood of generalized trust by 25 percent. Also, the male-only regression analyses reveal that, except for confidence in the army, mosque attendance is a significant and positive determinant for all trust outcomes including generalized trust. The findings support $\mathrm{H} 2$ partially yet do not support H3.

Table 5 presents the models for the same variables with the addition of confidence in courts, an item on the 2007 WVS. The analyses indicate that religion's influence become more noticeable for the trust models. Without exception, religious salience is significant for all models. While it has positive association with institutional trust items, in the same way as in 2001, the relationship turns out negative in generalized trust. The effect of religious salience rises up enormously from 2001 to 2007. For example, in 200165 percent increase in the odds of having confidence in government for people who favor religion is very important becomes 180 percent in 2007, holding other variables constant. Subjective religiosity still significantly predicts confidence in parliament, religious organization and government with the exception of generalized trust. There is considerable shift in the effect of the importance of God measure from the previous wave of the WVS (2001), which 
is positively associated with the all models excluding generalized trust outcome. The attendance variable illustrates similar characteristic with the previous wave of the WVS, but it is not significant predictor for confidence in parties' model additional to army model.

Table 6 reports the odds ratios for institutional trust and generalized trust variables that are obtained from WVS 2012. Although religion remains the strongest predictor of trust components, there are considerable changes in the religious predictors. The first noticeable shift is that religious salience becomes a less influential predictor in this period than subjective religiosity. Religious salience is not significant in the models of confidence in parties, army, courts and even generalized trust. On the other hand, subjective religiosity is positively associated with all institutional trust models, but not significant in generalized trust. The other religious predictor, importance of god, also loses its significant levels in confidence in political parties, army and courts. However, it significantly predicts generalized trust; namely, people who report God is very important in their life are less likely to trust strangers, else being equal.

Table 7 shows binary logistic regression analyses of religion and socio demographic measures on interpersonal trust outcomes. The results indicate that religious respondents are less likely trust people from different nations and religions. However, there is no significant relationship between religiosity's measures and trusting people who one meets for the first time. Religious salience significantly predicts trust in people who one personally knows. Religion is not statistically significant for the remaining models, trust neighbours and trust family.

Education is the most noteworthy control variable across models and time periods. Without exception, education is negatively associated with confidence in parties and government. This negative relationship extends to confidence in parliament in the 2007 data, and to confidence in religious organizations and trust neighbours in 2012. Education has positive effect only for generalized trust in 2001. Also, in Table 4, the odds ratios of employment measure show significant, strong and negative relationships with confidence in parliament, parties and government.

In sum, the current results demonstrate that (1) H1 is not supported across time periods, (2) the models support $\mathrm{H} 2$ partially in each time period, (3) except confidence in political parties, the 
findings for trust in government agencies do not validate $\mathrm{H} 3$, (4) H4 is firmly supported, (5) the only trust people who personally known model supports H5 while family and neighbours do not, (6) Last hypothesis is partially supported.

Table 1. Descriptive statistics (TWVS2001)

\begin{tabular}{lccccc}
\hline \multicolumn{1}{c}{ Variable } & $\mathrm{N}$ & \multicolumn{1}{c}{ Mean } & Std. Dev & Min. & Max. \\
\hline Confidence in Parliament & 2792 & 0.4584527 & 0.4983601 & 0 & 1 \\
Confidence in Religious & & & & & \\
Org. & 2798 & 0.7240886 & 0.4470522 & 0 & 1 \\
Confidence in Parties & 2785 & 0.2854578 & 0.4517133 & 0 & 1 \\
Confidence in Army & 2814 & 0.876688 & 0.3288534 & 0 & 1 \\
Confidence in Govern- & & & & & \\
ment & 2812 & 0.4630156 & 0.498719 & 0 & 1 \\
Generalized trust & 2811 & 0.1874778 & 0.390364 & 0 & 1 \\
Male & 2855 & 0.4945709 & 0.5000581 & 0 & 1 \\
Married & 2855 & 0.7485114 & 0.4339448 & 0 & 1 \\
Age & 2855 & 2.8287215 & 1.3687939 & 1 & 4 \\
Education & 2855 & 1.9071804 & 1.398568 & 0 & 5 \\
Income & 2855 & 2.1134851 & 1.5669178 & 0 & 9 \\
Employment & 2855 & 0.4714536 & 0.4992719 & 0 & 1 \\
Religious & 2855 & 0.8 & 0.4000701 & 0 & 1 \\
Importance of God & 2855 & 0.7940455 & 0.4044682 & 0 & 1 \\
Importance of Religion & 2855 & 0.8010508 & 0.3992797 & 0 & 1 \\
Attendance & 1412 & 2.4851275 & 1.3901261 & 0 & 4 \\
\hline
\end{tabular}

a Attendance includes only male sample. 
Table 2. Descriptive statistics (TWVS2007)

\begin{tabular}{lcllcc}
\hline Variable & $\mathrm{N}$ & Mean & Std. Dev & Min. & Max. \\
\hline Confidence in Parliament & 1278 & 0.600157 & 0.490058 & 0 & 1 \\
Confidence in Religious & & & & & \\
Org. & 1320 & 0.706818 & 0.455394 & 0 & 1 \\
Confidence in Parties & 1292 & 0.329721 & 0.470294 & 0 & 1 \\
Confidence in Army & 1328 & 0.861446 & 0.345611 & 0 & 1 \\
Confidence in Government & 1304 & 0.627301 & 0.483709 & 0 & 1 \\
Confidence in Courts & 1315 & 0.74981 & 0.433287 & 0 & 1 \\
Generalized trust & 1339 & 0.047797 & 0.213416 & 0 & 1 \\
Male & 1346 & 0.497771 & 0.500181 & 0 & 1 \\
Married & 1346 & 0.662704 & 0.472963 & 0 & 1 \\
Age & 1346 & 1.933135 & 0.943765 & 1 & 4 \\
Education & 1346 & 2.193908 & 1.495567 & 0 & 5 \\
Income & 1319 & 2.386657 & 2.351315 & 0 & 9 \\
Employment & 1334 & 0.589955 & 0.492026 & 0 & 1 \\
Religious & 1321 & 0.820591 & 0.38384 & 0 & 1 \\
Importance of God & 1339 & 0.761763 & 0.426164 & 0 & 1 \\
Importance of Religion & 1344 & 0.75 & 0.433174 & 0 & 1 \\
Attendance & 660 & 2.492424 & 1.353331 & 0 & 4 \\
\hline a Atenda & & & & &
\end{tabular}

a Attendance includes only male sample.

Table 3. Descriptive statistics (TWVS2014)

\begin{tabular}{lclccc}
\hline Variable & $\mathrm{N}$ & Mean & Std. Dev & Min. & Max. \\
\hline $\begin{array}{l}\text { Confidence in Parliament } \\
\text { Confidence in Religious }\end{array}$ & 1248 & 0.600962 & 0.489897 & 0 & 1 \\
Org. & 1271 & 0.778128 & 0.415669 & 0 & 1 \\
Confidence in Parties & 1253 & 0.372706 & 0.483718 & 0 & 1 \\
Confidence in Army & 1264 & 0.803006 & 0.397885 & 0 & 1 \\
Confidence in Government & 1260 & 0.63254 & 0.482305 & 0 & 1 \\
Confidence in Courts & 1271 & 0.781275 & 0.413545 & 0 & 1 \\
Generalized trust & 1220 & 0.127869 & 0.334081 & 0 & 1
\end{tabular}


Male

Married

Age

Education

Income

Employment

Religious

Importance of God

Importance of Religion

Trust Family

Trust Neighbours

Trust Known People

Trust First Time Meet

Trust Other Religion

Trust Other Nation

$\begin{array}{lllll}1271 & 0.492526 & 0.500141 & 0 & 1 \\ 1271 & 0.658537 & 0.474387 & 0 & 1 \\ 1271 & 2.111723 & 0.957414 & 1 & 4 \\ 1271 & 2.47915 & 1.453532 & 0 & 5 \\ 1251 & 4.665068 & 1.877586 & 0 & 9 \\ 1237 & 0.57882 & 0.493948 & 0 & 1 \\ 1259 & 0.849087 & 0.358107 & 0 & 1 \\ 1271 & 0.675846 & 0.468242 & 0 & 1 \\ 1271 & 0.663257 & 0.472782 & 0 & 1 \\ 1265 & 0.992885 & 0.084081 & 0 & 1 \\ 1261 & 0.872324 & 0.333862 & 0 & 1 \\ 1264 & 0.81962 & 0.384656 & 0 & 1 \\ 1262 & 0.232964 & 0.422887 & 0 & 1 \\ 1228 & 0.380293 & 0.485657 & 0 & 1 \\ 1227 & 0.399348 & 0.489964 & 0 & 1 \\ 626 & 2.43131 & 1.253186 & 0 & 4\end{array}$

${ }^{a}$ Attendance includes only male sample.

Figure 1. The percentages of Turkish people who think most people can be trusted across time periods (Derived from 1991-2012 WVS).

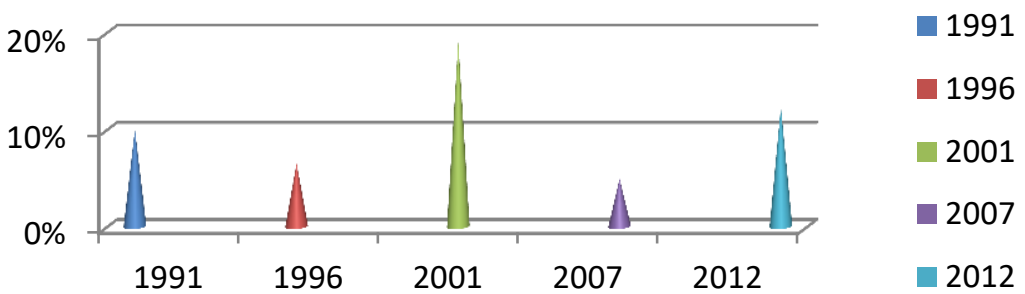


Table 4. Binary Logistic Regression Odds Ratios for Generalized and Institutional Trust Components (2001 WVS)

\begin{tabular}{|c|c|c|c|c|c|c|}
\hline & Confidence & Confidence & Confidence & Confidence & Confidence & Generalized \\
\hline Variable & Parliament & Religorg. & Parties & Army & Government & Trust \\
\hline Intercept & $-0.5698 * *$ & -0.4174 & $-1.0706 * * *$ & 0.5156 & $-0.3900 *$ & $-2.4591 * * *$ \\
\hline Male & 0.929 & 0.887 & 1.131 & 0.881 & 0.868 & 1.086 \\
\hline Married & $1.234 *$ & 1.058 & 1.041 & 0.946 & 0.993 & 1.246 \\
\hline Age & 0.988 & $1.098 *$ & 0.962 & $1.258 * * *$ & 1 & 1.069 \\
\hline Education & 0.97 & 0.959 & $0.923 * *$ & 1.012 & $0.86^{* * * *}$ & $1.193 * * *$ \\
\hline Income & 1.026 & 1.003 & 1.066 & $1.14 * *$ & $1.21 *$ & 1.176 \\
\hline Employed & $0.8^{*}$ & 0.854 & $0.782 *$ & 0.897 & $0.686 * * *$ & 1.136 \\
\hline Religious & $1.235^{*}$ & $1.79 * * *$ & 1.245 & 1.195 & $1.321 * *$ & $1.601 * *$ \\
\hline \multicolumn{7}{|l|}{ Importance } \\
\hline of god & 1.002 & $1.806 * * *$ & 1.119 & 1.339 & 0.976 & 0.964 \\
\hline \multicolumn{7}{|l|}{ Importance } \\
\hline of religion & $1.515 * *$ & $1.69 * * *$ & 1.261 & $1.679 * *$ & $1.652 * * *$ & $0.751 *$ \\
\hline$N$ & 2792 & 2798 & 2785 & 2814 & 2812 & 2811 \\
\hline Rsquare & 0.03 & 0.11 & 0.02 & 0.04 & 0.05 & 0.03 \\
\hline Attendance ${ }^{a}$ & $1.147 * *$ & $1.281 * * *$ & $1.193 * *$ & 1.071 & $1.101 *$ & $1.123^{*}$ \\
\hline
\end{tabular}

$* \mathrm{p}<.05 ; \quad * * \mathrm{p}<.01 ; * * * \mathrm{p}<.001$

a These models include only male sample and were employed separately. 
Table 5. Binary Logistic Regression Odds Ratios for Generalized and Institutional Trust Components (2007 WVS)

\begin{tabular}{|c|c|c|c|c|c|c|c|}
\hline Variable & $\begin{array}{l}\text { Confiden- } \\
\text { ce Parlie- } \\
\text { ment }\end{array}$ & $\begin{array}{l}\text { Confiden- } \\
\text { ce Reli- } \\
\text { gorg }\end{array}$ & $\begin{array}{l}\text { Confidence } \\
\text { Parties }\end{array}$ & $\begin{array}{l}\text { Confiden- } \\
\text { ce Army }\end{array}$ & $\begin{array}{l}\text { Confiden- } \\
\text { ce Go- } \\
\text { vernment }\end{array}$ & $\begin{array}{l}\text { Confiden- } \\
\text { ce Courts }\end{array}$ & $\begin{array}{l}\text { Generaz- } \\
\text { lized } \\
\text { Trust }\end{array}$ \\
\hline Intercept & -0.8998 & $-1.3942 * *$ & $-1.6958 * * *$ & -0.138 & $-0.6843^{*}$ & 0.1281 & -3.1920 \\
\hline Male & 0.884 & 0.632 & 1.009 & $1.793 * *$ & 1.095 & 1.191 & 1.093 \\
\hline Married & 1.268 & $2.217 * * * *$ & 1.07 & 1.178 & 1.291 & 1.144 & 1.76 \\
\hline Age & 1.047 & 1.008 & $1.18^{*}$ & $1.298^{*}$ & 0.945 & 1.147 & 0.97 \\
\hline Education & $0.835 * *$ & 1.102 & $0.873 *$ & 1.154 & $0.79 * * *$ & 0.923 & 0.998 \\
\hline Income & 1.035 & $0.87 * * *$ & 0.974 & 0.959 & 0.965 & 0.993 & 1.003 \\
\hline Employed & 0.867 & 0.827 & 1.188 & $1.565^{*}$ & 1.092 & 0.857 & 1.108 \\
\hline Religious & $1.664^{* *}$ & $2.54 * * *$ & 1.363 & 1.364 & $1.98 * * *$ & $1.438 *$ & 2.208 \\
\hline $\begin{array}{l}\text { Importance } \\
\text { of god }\end{array}$ & $2.06 * * *$ & $1.467^{*}$ & $1.503 *$ & $2.193^{* * *}$ & $1.843 * *$ & $1.628 * *$ & 0.809 \\
\hline $\begin{array}{l}\text { Importance } \\
\text { of religion }\end{array}$ & $1.802 * *$ & $2.926 * * *$ & $1.438 *$ & $1.839 * *$ & $2.805 * * *$ & $1.684 * *$ & $0.369 * *$ \\
\hline $\mathrm{N}$ & 1225 & 1257 & 1237 & 1266 & 1246 & 1254 & 1274 \\
\hline Rsquare & 0.11 & 0.11 & 0.06 & 0.06 & 0.18 & 0.07 & 0.02 \\
\hline Attendance & $1.589 * * *$ & $2.09 * * *$ & 1.153 & 1.149 & $1.441 * * *$ & $1.271^{*}$ & $1.365 *$ \\
\hline
\end{tabular}

$* \mathrm{p}<.05 ; \quad * * \mathrm{p}<.01 ; \quad * * * \mathrm{p}<.001$

a These models include only male sample and were employed separately. 
Table 6. Binary Logistic Regression Odds Ratios for Generalized and Institutional Trust Components (2014 WVS)

\begin{tabular}{|c|c|c|c|c|c|c|c|}
\hline Variable & $\begin{array}{l}\text { Confiden- } \\
\text { ce Parli- } \\
\text { ament }\end{array}$ & $\begin{array}{l}\text { Confiden- } \\
\text { ce Reli- } \\
\text { gorg }\end{array}$ & $\begin{array}{l}\text { Confiden- } \\
\text { ce Parties }\end{array}$ & $\begin{array}{l}\text { Confiden- } \\
\text { ce Army }\end{array}$ & $\begin{array}{l}\text { Confiden- } \\
\text { ce Go- } \\
\text { vernment }\end{array}$ & $\begin{array}{l}\text { Confiden- } \\
\text { ce Courts }\end{array}$ & $\begin{array}{l}\text { Gene- } \\
\text { razli- } \\
\text { zed } \\
\text { Trust }\end{array}$ \\
\hline Intercept & -0.1737 & -0.2402 & $-1.2507 * *$ & 0.0395 & -0.5328 & -0.2 & $\begin{array}{l}-2.9493 \\
* * *\end{array}$ \\
\hline Male & 1.065 & 0.89 & $1.624^{* *}$ & 0.686 & 1.315 & 0.932 & 1.629 \\
\hline Married & 1.106 & 1.146 & 0.935 & 1.123 & 1.281 & 1.283 & 0.815 \\
\hline Age & 0.913 & 0.96 & 1.037 & $1.363 * *$ & 0.923 & $1.243^{*}$ & 1.214 \\
\hline Education & $0.86 * *$ & $0.886 *$ & $0.893 *$ & 1.074 & $0.842 * *$ & 0.99 & 1.151 \\
\hline Income & 1.012 & 0.997 & 1.049 & 0.982 & 1.014 & 1.028 & 1.09 \\
\hline Employed & 1.335 & 1.158 & 0.955 & $1.699 * *$ & 0.976 & 1.058 & 0.812 \\
\hline Religious & $1.613^{* *}$ & $3.974 * * *$ & $1.846 * *$ & $1.958 * *$ & $2.16 * * *$ & $2.142 * * *$ & 1.268 \\
\hline $\begin{array}{l}\text { Importance } \\
\text { of god }\end{array}$ & $1.351 *$ & $1.577^{*}$ & 1.274 & 0.733 & $2.132 * * *$ & 1.25 & $0.585^{* *}$ \\
\hline $\begin{array}{l}\text { Importance } \\
\text { of religion }\end{array}$ & $1.423 * *$ & $1.881 * * *$ & 0.807 & 1.197 & $1.334 *$ & 1.04 & 0.966 \\
\hline $\mathrm{N}$ & 1187 & 1208 & 1192 & 1201 & 1198 & 1208 & 1164 \\
\hline Rsquare & 0.05 & 0.11 & 0.04 & 0.03 & 0.1 & 0.04 & 0.03 \\
\hline Attendance & $1.589 * * *$ & $2.09 * * *$ & 1.153 & 1.149 & $1.803 * * *$ & $1.594^{* *}$ & $1.365 *$ \\
\hline
\end{tabular}

$* \mathrm{p}<.05 ; \quad * * \mathrm{p}<.01 ; \quad * * * \mathrm{p}<.001$

a These models include only male sample and were employed separately. 
Table 7. Binary Logistic Regression Odds Ratios for Particularized Trust Components (2014 WVS)

\begin{tabular}{|c|c|c|c|c|c|c|}
\hline Variable & $\begin{array}{l}\text { Trust } \\
\text { Another } \\
\text { Nation }\end{array}$ & $\begin{array}{l}\text { Trust Anot- } \\
\text { her Reli- } \\
\text { gion }\end{array}$ & $\begin{array}{l}\text { Trust First } \\
\text { Time }\end{array}$ & $\begin{array}{l}\text { Trust } \\
\text { Known } \\
\text { People }\end{array}$ & $\begin{array}{l}\text { Trust } \\
\text { Neighbo- } \\
\text { urs }\end{array}$ & $\begin{array}{l}\text { Trust } \\
\text { Family }\end{array}$ \\
\hline Intercept & -0.3924 & -0.5176 & $-1.9338 * *$ & $1.5474 * *$ & $1.816^{* * * *}$ & $5.5635 * *$ \\
\hline Male & 1.152 & 1.205 & 1.284 & 0.972 & 1.353 & 0.778 \\
\hline Married & 0.864 & 0.836 & 0.798 & 0.82 & 1.037 & 1.643 \\
\hline Age & 0.993 & 1.079 & $1.249 * *$ & 1.176 & $1.317^{*}$ & 0.583 \\
\hline Education & 1.047 & 1.099 & 1.02 & 0.962 & $0.847^{*}$ & 0.685 \\
\hline Income & 1.043 & 1.016 & 1.069 & 0.996 & 0.999 & 1.197 \\
\hline Employed & 1.283 & 1.154 & 1.007 & 0.731 & 1.188 & 1.233 \\
\hline Religious & $0.696 *$ & $0.61 * *$ & 1.03 & 0.97 & 1.01 & 2.549 \\
\hline $\begin{array}{l}\text { Importance } \\
\text { of god }\end{array}$ & 0.976 & 1.026 & 0.884 & 0.851 & 0.694 & 0.311 \\
\hline $\begin{array}{l}\text { Importance } \\
\text { of religion }\end{array}$ & 0.86 & 0.877 & 1.008 & $1.432 \%$ & 0.937 & 2.897 \\
\hline $\mathrm{N}$ & 1165 & 1166 & 1200 & 1201 & 1198 & 1234 \\
\hline Rsquare & 0.03 & 0.03 & 0.03 & 0.01 & 0.03 & 0.02 \\
\hline Attendance & 0.821 & $0.758 *$ & 0.86 & 1.22 & $1.553^{*}$ & 3.779 \\
\hline
\end{tabular}

$* \mathrm{p}<.05 ; \quad * * \mathrm{p}<.01 ; * * * \mathrm{p}<.001$

a These models include only male sample and were employed separately.

\section{Discussion and Conclusion}

This study both contributes to the literature on social cohesion and enhances previous literature by focusing on a predominantly Muslim country. Using the three waves (2001, 2007, and 2012) of the WVS, I have estimated the effect of religion on trust levels of the population in order to find the possible sequence relationship with social cohesion of Turkey. In addition, this study further estimates the longitudinal changes of religions' effect on interpersonal 
and institutional trust measures. Though Turkey has undergone a great deal of modernization within the last century, findings indicate that religion has a great deal of influence in Turkey's public attitudes.

In summary, this research discovers that (1) the positive effect of at least one religious outcome exists on institutional trust models across time periods, (2) religion has both negative and positive effect on generalized trust measures, (3) among particularized trust measures, trust in people who one personally knows is only predicted by religion, (4) education considerably decreases people's confidence in political institutions which works against the effects of religious measures, (5) the positive relationship between generalized trust and political trust is not available in Turkish case.

First, it is important to recognize that this paper endeavours to advance the existing literature on social cohesion by utilizing religion and trust framework through the application of a comparative view with a non-Western, non-Christian nation. Furthermore, this study is one of the first examinations to research religion and trust in a society that is majority Muslim yet also democratic and connected closely to secular European history.

In addition, in order to understand the low level of generalized trust in Turkey, several explanations should be addressed. First, trust is a complex and an abstract term which may have different meanings across culture ${ }^{45}$. Considering the traditional collective cultural context of Turkey trust is expensive and risky, and not easily offered to strangers. In other words, caution is the cultural basis of social relationships between strangers, and trust requires at least a modicum of interaction. Second, the questions are somewhat vague; for example, the term "can't be too careful" can be understood in multiple ways. Third, in the Islamic context trusting comes after then be trusted. Namely, Muslims are obligated to be trustworthy before trusting others ${ }^{46}$, which is not an easy task to achieve.

The current findings reveal mixed effects of religion that are somewhat contradictory. The longitudinal models indicate that religiosity in 2001 and attendance in 2001, 2007 and 2014 are all

45 You, "Social Trust".

46 Erhan Tecim, Sosyal Guven (Konya: Cizgi Kitabevi, 2015). 
positive predictors for generalized trust. On the other hand, importance of religion in 2001 and 2007 and importance of God in 2012 are negative determinants of generalized trust. The possible explanation for this phenomenon might be related to various dimensions of religion. Subjective religiosity (collective identity) and attendance (collective behaviour) represent collective dimensions of religion. Subjective religiosity assigns a religious identity ${ }^{47}$ which can promote trust among people who hold the same identity (considering more than 99 percent of Turkish people are Muslim). This explanation can also be validated by addressing the trust in other nations and trust in other religions in Table 7. Only subjective religiosity is negatively associated with trust in other nations and trust in other religions. The effect of attendance can be predictable as previous studies indicate that religious participation is a significant "social resource" which leads people to more voluntary associations and civic engagements (Daniels and Von der Ruhr, 2010).

In order to understand the current findings more accurately, Ibn Khaldun's, $14^{\text {th }}$ century Muslim sociologist and historian, theory of trust in traditional Muslim societies needs to be addressed. Ernest Gellner (2000) ${ }^{48}$ analyzes Ibn Khaldun's main premise that "anarchy engenders trust, and government destroys it." In other words, to survive in traditional tribal societies, clan members have to trust the member; this was the only way to prevent anarchy. However, when tribe members decided to be citizen of a central government, they do not need such a strong solidarity because government is responsible to prevent anarchy. By the time tribe members become citizens and the kinship is going to disappear as it is happened today's modern world. This explains basically how Ibn Khaldun understood the social solidarity in tribal and urban lifestyles $^{49}$. From his theoretical argument, the low level of trust in others and high-level confidence in institutions is as expected. This paper is marked by several limitations in its analysis of religious change in Turkey.

\footnotetext{
47 Murat Yilmaz, Change and Continuity in Patterns and Levels of Religious Values, Commitment, and Practices in Turkey (United States -- Texas: The University of Texas at San Antonio, M.S., 2013).

48 Gellner, Trust, Cohesion, and the Social Order.

49 Ibn Khaldun, The Muqaddimah: An Introduction to History (PRINCETON UNIV PRESS@, 1994).
} 
The cross-sectional nature of WVS data is problematic for this study. As these variables were originally conceived in a Western context-with Western religions in mind-many of the religious variables were not appropriate in the context of Islam. Furthermore, the methodological approach of this study only allows answering the question of "what" rather than "how". Finally, this one wave of data set only tells about the certain points of the time, so that further longitudinal studies will provide more information to understand the correct story of the issue.

\section{REFERENCES}

Alesina, Alberto - La Ferrara, Eliana. "Who Trusts Others?" Journal of Public Economics 85/2 (01 Ağustos 2002), 207-234. https://doi.org/10.1016/S00472727(01)00084-6

Brehm, John - Rahn, Wendy. "Individual-Level Evidence for the Causes and Consequences of Social Capital". American Journal of Political Science 41/3 (1997), 9991023. https://doi.org/10.2307/2111684

Daniels, Joseph P. - Ruhr, Marc von der. "Trust in Others: Does Religion Matter?" Review of Social Economy 68/2 (01 Haziran 2010), 163-186. https://doi.org/10.1080/00346760902968447

Delhey, Jan - Newton, Kenneth. "Who trusts?: The origins of social trust in seven societies". European Societies 5/2 (01 Ocak 2003), 93-137. https://doi.org/10.1080/1461669032000072256

Durkheim, Émile - Swain, Joseph Ward. The Elementary Forms of the Religious Life. Glencoe, Ill.: Free Press, 1954.

Ekmekçi, Faruk. "Marazi bir durum olarak Türkiye'de niyet siyaseti: Türkiye'de toplumsal güven eksikliği ve bunun siyasal sonuçları". Uluslararası İnsan Bilimleri Dergisi 7/2 (2010). https://www.acarindex.com/dosyalar/makale/acarindex1423936498.pdf

Fukuyama, Francis. Trust: The Social Virtues and The Creation of Prosperity. New York, NY: Free Press, First Paperback Edition., 1996.

Gellner, Ernest. Trust, Cohesion, and the Social Order, 2000.

Hunter, James Davison. To Change the World: The Irony, Tragedy, and Possibility of Christianity in the Late Modern World. New York: Oxford University Press, 1st edition., 2010.

Huntington, Samuel P. The Clash of Civilizations and the Remaking of World Order. Simon \& Schuster, 1998.

INGLEHART, RONALD. Modernization and Postmodernization: Cultural, Economic, and Political Change in 43 Societies. Princeton University Press, 1997. https://doi.org/10.2307/j.ctv10vm2ns

Inglehart, Ronald. "Trust, well-being and democracy". Democracy and Trust. ed. Mark E. Warren. 88-120. Cambridge: Cambridge University Press, 1999. https://doi.org/10.1017/CBO9780511659959.004

Jamal, Amaney. "When Is Social Trust a Desirable Outcome? Examining Levels of Trust in the Arab World". Comparative Political Studies 40/11 (11 Ocak 2007), 13281349. https://doi.org/10.1177/0010414006291833

Khaldun, Ibn. The Muqaddimah: An Introduction to History. PRINCETON UNIV PRESS@, 49395th edition., 1994.

Köksal, M. Emin. Din ve Siyaset - Siyasal Davranış ve Dindarlık. Ankara: Vadi, 1997. 
La Porta, Rafael vd. "Trust in Large Organizations". The American Economic Review 87/2 (1997), 333-338. https://www.jstor.org/stable/2950941

Leonard, Rosemary - Bellamy, John. "The Relationship between Bonding and Bridging Social Capital among Christian Denominations across Australia". Nonprofit Management and Leadership 20/4 (2010), 445-460. https://doi.org/10.1002/nml.20004

Li, Tianyuan - Fung, Helene H. "Age Differences in Trust: An Investigation across 38 Countries". The Journals of Gerontology. Series B, Psychological Sciences and Social Sciences 68/3 (Mayıs 2013), 347-355. https://doi.org/10.1093/geronb/gbs072

Mencken, F. Carson vd. "In God We Trust: Images of God and Trust in the United States among the Highly Religious". Sociological Perspectives 52/1 (01 Mart 2009), 2338. https://doi.org/10.1525/sop.2009.52.1.23

Misztal, Barbara. Trust in Modern Societies: The Search for the Bases of Social Order. Polity, 1 edition., 2013.

Proctor, James. "Religion as Trust in Authority: Theocracy and Ecology in the United States". Annals of the Association of American Geographers 96/1 (01 Mart 2006), 188-196. https://doi.org/10.1111/j.1467-8306.2006.00508.x

Putnam, Robert. Bowling Alone: The Collapse and Revival of American Community. New York: Simon \&amp; Schuster, 2000.

Putnam, Robert D. vd. Making Democracy Work: Civic Traditions in Modern Italy. Princeton, NJ: Princeton University Press, 1st edition., 1994.

Putnam, Robert D. "Social Capital and Public Affairs". Bulletin of the American Academy of Arts and Sciences 47/8 (1994), 5-19. https://doi.org/10.2307/3824796

934 | db Sasaki, Masamichi - Marsh, Robert M. Trust: Comparative Perspectives. BRILL, 2012.

Smidt, Corwin. "Religion and Civic Engagement: A Comparative Analysis". The ANNALS of the American Academy of Political and Social Science 565/1 (01 Eylül 1999), 176-192. https://doi.org/10.1177/000271629956500112

Sullivan, Adam John. Social Trust and Denominational Concentration: A Cross-National Examination of Religion and Trust. ProQuest Dissertations Publishing, 2013.

Tan, Jonathan H. W. - Vogel, Claudia. "Religion and Trust: An Experimental Study". Journal of Economic Psychology 29/6 (01 Aralık 2008), 832-848. https://doi.org/10.1016/j.joep.2008.03.002

Tecim, Erhan. Sosyal Guven. Konya: Cizgi Kitabevi, 2015.

Traunmüller, Richard. "Moral Communities? Religion as a Source of Social Trust in a Multilevel Analysis of 97 German Regions". European Sociological Review 27/3 (01 Haziran 2011), 346-363. https://doi.org/10.1093/esr/jcq011

Uslaner, Eric M. "Trust and Social Bonds: Faith in Others and Policy Outcomes Reconsidered". Political Research Quarterly 57/3 (2004), 501-507. https://doi.org/10.2307/3219859

Uslaner, Eric M. - Brown, Mitchell. "Inequality, Trust, and Civic Engagement". American Politics Research 33/6 (01 Kasım 2005), 868-894. https://doi.org/10.1177/1532673X04271903

Welch, Michael R. vd. "Trust in God and Trust in Man: The Ambivalent Role of Religion in Shaping Dimensions of Social Trust". Journal for the Scientific Study of Religion 43/3 (2004), 317-343. https://doi.org/10.1111/j.1468-5906.2004.00238.x

Yilmaz, Murat. Change and Continuity in Patterns and Levels of Religious Values, Commitment, and Practices in Turkey. United States -- Texas: The University of Texas at San Antonio, M.S., 2013.

http://search.proquest.com/docview/1442792237/abstract/9B245411930C409 OPQ/1

You, Jong-sung. "Social Trust: Fairness Matters More Than Homogeneity". Political Psychology 33/5 (01 Ekim 2012), 701-721. https://doi.org/10.1111/j.14679221.2012.00893.x 


\section{Din ve Güven Illişkisinin Türkiye Perspektifinden \\ incelenmesi*}

Murat YILMAZ**

\section{Ayrıntılı Özet}

Bu çalışma, Dünya Değerler Anketleri'nden (WVS) alınan Türkiye örneğini kullanarak din ve güven arasındaki ilişkiyi araştırmaktadır. Toplumların sosyal sermayesi olarak kuramsallaştırılan güven, sosyal uyum için önemli bir belirleyici olarak kabul edilmektedir. Sosyolojinin babaları, Marx, Durkheim ve Weber ve birçok felsefi düşünür, toplumu bir arada tutan şey nedir sorusunu yanıtlamaya büyük önem vermişlerdir. Güven kavramı, teorik açıklamalarının yanı sıra deneysel varsayımlar yapmak için sosyal uyumu ölçmek üzere bir değişken olarak kullanılmıştır.

Daha önceki çalışmalar, gelișmis ülkelerin yüksek düzeyde güven duygusuna sahip vatandaşlara sahip olduklarını öne sürerek, ülkelerin güven endeksi ve kalkınmışlık arasında pozitif bir bağlantı bulmuşlardır. Ayrıca mevcut literatür, başkalarına güvenmek ile sivil ve devlet kurumlarına güven arasında bir ilişki olduğunu belirtmektedir. Son yirmi yıl içinde güven (özellikle genelleştirilmiş güven) toplumsal birlik ve uyum için önemli bir mesele olarak kabul edilmektedir. Modern toplumların, sahip oldukları merkezi otorite nedeniyle sosyal uyum için daha az genel bir güven ihtiyacına sahip olduğu varsayımı, araştırmacıların güveni daha önceki yıllarda göz ardı etmelerinin bir nedeni olarak kabul edilebilir. Bununla birlikte, bireyselcilikle birlikte çok çeşitli kültürlerin bir arada yaşamaya başlaması, güvenin sosyal entegrasyonu artıran bir ahlaki değer olarak önem kazanmasına yol açmıştır. Günümüzde sosyoloji, siyaset bilimi ve ekonomi alanında yapılan araştırmalar, güven olgusunu karmaşık modern toplumlarda sosyal uyumun önemli bir yönü olarak tanımlamaktadır. Bu çalışma, modern Türkiye'yi tasvir eden tarihsel arka planı ortaya koymanın yanı sıra, din ve güven arasındaki ilişsinin temel kavramlarını ve temel teorik açıklamalarını tanımlamaktadır. Bu şekilde, bu toplumdaki din ve güven arasındaki bağın karmaşık yönlerini daha verimli bir şekilde ifade edebileceğini varsaymaktadır.

Pek çok değere sahip olan dini gelenek ve inanışlar, toplum arasında güven birikiminin oluşması için de çok önemli bir işleve haizdir. Türkiye açısından önemli bir sosyal dönüșüm dönemi olan 2001'den 2012'ye kadar din ve güven arasındaki uzun vadeli ilişkinin araştırıldığı bu makalede, dinin ortak değişkenlerinin güven sonuçları üzerindeki etkilerinin tutarlı olduğu gözlemlenmiştir. Bununla bir-

* Bu makale "Religion and Trust: Turkish Case" başlıklı yüksek lisans tezimden (Baylor University, 2015) üretilmiştir.

** Dr., Hitit Universitesi İlahiyat Fakültesi Felsefe ve Din Bilimleri Bölümü, Din Sosyolojisi Anabilim Dalı Öğretim Üyesi, muratyilmaz@hitit.edu.tr; Orcid Id: https://orcid.org/0000-0001-7083-4981 
likte, her ne kadar bulgular mevcut literatürü desteklemiş olsa da sonuçların bir kısmı bazı farklılıklar arzetmektedir. Yani, dini bağlılı̆̆ın ve davranışların etkileri güven sonuçlarına göre değişir. Kısaca özetleyecek olursak, bu araştırma aşağıdaki bulguları ortaya koymuştur: (1) en az bir din değişkeni bütün zaman dönemleri boyunca kurumsal güven modelleri üzerinde olumlu etkisi vardır, (2) dinin, genelleştirilmiş güven değişkeni üzerinde hem olumsuz hem de olumlu etkisi vardır, (3) özelleştirilmiş güven değişkenleri arasında, şahsen tanıdığı kişilere güven sadece din tarafından öngörülmektedir, (4) eğitim, insanların dini önlemlerin etkilerine aykırı çalışan siyasi kurumlara olan güvenini önemli ölçüde azaltır, (5) genelleşmiş güven ile siyasi güven arasındaki pozitif ilişki bulunmaktadır.

Mevcut bulgular, dinin güven değerleri üzerinde farklı etkilerini ortaya koymaktadır. Boylamsal modeller, 2001'deki dindarlığın ve 2001, 2007 ve 2014'teki katılımın genelleştirilmiş güven için olumlu yordayıcılar olduğunu göstermektedir. Öte yandan 2001 ve 2007'de dinin önemi ve 2012'de Tanr'nın önemi genelleştirilmiş güvenin olumsuz belirleyicileridir. Bu olgunun olası açıklaması, dinin çeşitli boyutlara sahip olmasına dayandırılabilir. Öznel dindarlık (kolektif kimlik) ve dini katılım (kolektif davranış), dinin kolektif boyutlarını temsil eder. Öznel dindarlık, aynı kimliğe sahip insanlar arasında güveni artırabilecek bir dini kimlik sağlar (Türk halkının yüzde 99'undan fazlasının Müslüman olduğu düşünülürse). Bu açıklama, çalışmanın bulgularında ortaya koyulan diğer milletlere ve diğer dinlere olan güven konusu ele alınarak da doğrulanabilir. Daha önceki araştırmalar, dini katılımın insanları vakıflara ve sivil katılımlara yönlendiren önemli bir "sosyal kaynak" olduğunu gösterdiğinden, dini katılımın bulgularda elde edilen pozitif etkisini açıklamaktadır (Daniels ve Von der Ruhr, 2010).

Ayrıca, bu makale güven bileşenleri arasındaki olası ilişkileri araştırmış olup ortaya çıkan sonuçlar önceki bulguları desteklemektedir. Dolayısıyla sosyal sermaye olarak oluşturulmuş teorik çerçeve Türkiye örneğinde güven değişkenleri arasındaki ilişkiyi açıklayamamaktadır. Bu çalışma, İbn-i Haldun Asabiye teorisi de dâhil olmak üzere bulgular için birkaç olası alternatif açıklamayı ortaya koymaktadır.

Mevcut bulguları daha doğru anlayabilmek için 14. yüzyıl Müslüman sosyolog ve tarihçisi İbn Haldun'un geleneksel Müslüman toplumlarda güven teorisine değinmek gerekmektedir. Ernest Gellner (2000), İbn Haldun'un "anarşi güveni doğurur ve merkezi yönetim onu yok eder" şeklindeki ana önermesini ortaya koymuş ve bu vecihle Batı'da bilinen "sosyal sermaye" teorisinden farklı bir anlayışın mevcut olduğunu ifade etmiştir. İbn-i Haldun'nun bu teorisini kısa ifade edecek olursak, geleneksel kabile toplumlarında hayatta kalabilmek için klan üyeleri diğer üyelere ölümüne güvenmek zorundadır; üyeler ancak birlikte hayatta kalabileceklerinin ve kendilerini savunmain tek yolunun bu olduğunu bilmektedirler ve anarşiyi önlemenin tek yolu budur. Ancak, klan üyeleri merkezi bir hükümetin vatandaşı olmaya karar verdiklerinde, bu kadar güçlü bir dayanışmaya ihtiyaçları yoktur, çünkü hükümet anarşiyi önlemekle sorumludur. Kabile üyeleri vatandaş olunca günümüz modern dünyasında olduğu gibi akrabalık bağları zayıflayacak ve zamanla ortadan kalkmaya yüz tutacaktır. Bu durum İbn Haldun'un kabile ve şehir yaşam tarzlarındaki toplumsal dayanışmayı nasıl anladığını izah etmektedir.

Bu makale, Türkiye'deki dini değişim analizinde çeşitli sınırlamalara sahiptir. WVS verilerinin kesitsel yapısı bu çalışma için sorunludur. Bu çalışmada kullanılan değiskenler başlangıçta Batılı bir bağlamda -Batı dinleri göz önünde bulundurularak- düşünüldüğünden, dini değişkenlerin bazıları Müslüman toplumlara 
sorulmaya müsait değildir. Ayrıca, bu çalışmanın metodolojik yaklaşımı, "nasıll" sorusundan çok "ne" sorusunun yanıtlanmasına izin vermektedir. Son olarak, bu kullanılan veri seti sadece zamanın belirli noktalarında bulunan durumu açıklamaktadır. Dolayısıyla daha fazla boylamsal (panel) çalışmalar yapılması gelecekte konunun doğru hikâyesini anlamak için daha fazla bilgi sağlayacaktır.

Anahtar Kelimeler: Din, Güven, İslam, Türkiye, Sosyoloji

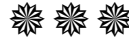

$\mathrm{db} \mid 937$ 